\title{
PRELIMINARY SURVEY OF RIPARIAN VEGETATION OF THE SPRING-FED STREAM KYUNJA GAD, A TRIBUTARY OF RIVER MANDAKINI, RUDRPRAYAG GARHWAL, UTTARAKHAND
}

\author{
Pratibha Baluni ${ }^{1}$ and Ashita Chandola ${ }^{2}$
}

\author{
${ }^{1}$ Ecology Lab, Department of Botany, A.P.B. Govt. P.G. College Agustyamuni-246421,District - \\ Rudraprayag, Uttarakhand. \\ ${ }^{2}$ Ex- Faculty in Botany, R/O University Residences, Ayarpata, Nainital- 263001
}

Corresponding Author Email id: pankajpaurii@gmail.com

Received: 12.10.2019; Revised: 17.11.2019; Accepted: 12.12.2019

OSociety for Himalayan Action Research and Development

\begin{abstract}
The vegetation around a river or stream is called riparian vegetation. The quality of riparian vegetation has direct influence on the quality of life in water. The fallen leaves and twigs of the riparian flora accumulated in side streams and after some time makes a detritus which becomes an intrinsic part of the stream and contributes to its productivity as food of various benthic and nektonic organisms. In the present contribution, an attempt has been made to enlist the riparian vegetation around spring-fed stream Kyunja gad, tributary of the glacier-fed river Mandakini in District Rudrprayag, Garhwal, Uttarakhand. Total twenty-one tree species and twelve species of herbs and shrubs were observed.
\end{abstract}

Keywords: Riparian, Kyunja gad, Mandakini, Rudraprayag

\section{Introduction}

The importance of riparian vegetation has been well understood by the aquatic biologists and hence lot of work has been conducted on this aspect. The submerged flora contributes towards productivity through photosynthesis and also by contributing nutrients. The catchment riparian helps in binding soil and avoids its erosion, thus quality of stream is improved (Sagir and Dobriyal, 2018). The influence of riparian vegetation on riverine ecology has been studied by Pusey and Arthington (2003) and Rios and Bailey (2006). In Garhwal region, the riparian vegetation is studied by Balodi, et.al. (2004) in Eastern Nayar, Aziem et.al. (2016) in Bhilangana valley and Sagir and Dobriyal $(2017,2018)$ in the river Western Nayar. In the present contribution an attempt has been mede to study the riparian vegetation around stream Kunja gad in Rudrprayag Garhwal.

\section{Material and Methods}

The Kyunja Gad is a tributary of the snow-fed River Mandakani in District Rudrprayag Garhwal Uttarakhand. It is situated in the Latitude $30^{\circ} 25^{\prime}$ $45^{\prime \prime} \mathrm{N}$ and Longitude $79^{\circ} 08^{\prime} 35^{\prime \prime} \mathrm{E}$ and receives water from numerous springs, underground seepage and surface runoff. The riparian vegetation of the stream was studied around Senagarsari. Plants were identified by using local names consulted by the local inhabitants and then correlated by using different available floras. Subject experts of HNB Garhwal Uniersity, Srinagar Garhwal and Kumaun University were also consulted.

\section{Results and Discussion}

A total of 21 tree species and 12 herbs and shrub species were identified and presented in Table 1. Out of these 14 plants were known to be used as medicinal plants. 
Table 1: List of Riparian vegetation along the Kyunja Gad $1^{\text {st }}$ order stream.

\begin{tabular}{|c|c|c|c|c|}
\hline S.No & SCIENTIFIC NAME & COMMON NAME & FAMILY & $\begin{array}{l}\text { AVAILABILITY } \\
\text { (M=Medicinal) }\end{array}$ \\
\hline $\mathbf{A}$ & \multicolumn{4}{|c|}{ Trees } \\
\hline 1 & $\begin{array}{l}\text { Cedrus deodara (Roxb.ex } \\
\text { Lambert.).Don }\end{array}$ & Devdar & Pinaceae & Common (M) \\
\hline 2 & Rhododendron arboreum Smith & Burans & Ericaceae & Common (M) \\
\hline 3 & $\begin{array}{l}\text { Aesculus indica (Wall.ex Camb.) } \\
\text { Hook.f. }\end{array}$ & Paangar & Hippocastanaceae & Common \\
\hline 4 & Alnus nepalensis D.Don & Uthis & Betulaceae & Common \\
\hline 5 & Capressus torulosa D.Don & Bhotiya badam & Betulaceae & Occasional \\
\hline 6 & Celtis australis Linn & Khadic & Ulmaceae & Common \\
\hline 7 & Cinnamomum lumala Nees & Daalchini/tejpata & Lauraceae & Occasional \\
\hline 8 & Citurus medica Linn & Narangi & Rutaceae & Common \\
\hline 9 & Occulus laurifolius DC & Tilkar/tilfada & Menispermaceae & Common \\
\hline 10 & Dalbergia sissoo Roxb. & Surai & Cupressaceae & Common \\
\hline 11 & Ficus benghalensis Linn. & Timla & Moraceae & Common \\
\hline 12 & Grewia optiva J.R Drumn. ex Burrett & Bhemal & Tiliaceae & Common \\
\hline 13 & Juglans regia Linn. & Akhroot/akhod & Juglandaceae & Common $(\mathrm{M})$ \\
\hline 14 & Mangifera indica Linn. & Aam & Anacardiaceae & Common \\
\hline 15 & Myrica esculenta (butch-Ham.ex.D.Don & Kafal & Myricaceae & Common (M) \\
\hline 16 & Prunus cerasoides D.Don. xyn & Padam/ paiyan & Rosaceae & Common (M) \\
\hline 17 & Prunus persica $(\mathrm{L})$ Batsch & Aadu & Rosaceae & Common $(\mathrm{M})$ \\
\hline 18 & Punica coommunis L. & Annar & Punicaceae & Common (M) \\
\hline 19 & Pyrus communis L. & Naspati & Rosaceae & Common \\
\hline 20 & Pyrus pashia Buch-hem.ex. D.Don & Mehal & Rosaceae & Common $(\mathrm{M})$ \\
\hline 21 & Toona ciliata M.Roem.Syn. & Tun & Meliaceae & Common \\
\hline B & \multicolumn{4}{|c|}{ WOODY CLIMBERS/ SHRUBS/ HERBS } \\
\hline 22 & Berberis asiatica Roxb. ex DC & Kilmoda & Berberidaceae & Common \\
\hline 23 & Cannabis sativa Linn. & Bhang & Cannabaceae & Common \\
\hline 24 & $\begin{array}{l}\text { Carissa opaca Stapf ex Haines syn. } \\
\text { Carrisa spinarum A.DC. }\end{array}$ & Karonda & Apocynaceae & Common \\
\hline 25 & Cannabis sativa Linn. & Bhang & Cannabaceae & Common \\
\hline 26 & Datura stramonium Linn. & Dhatura & Solanaceae & Common (M) \\
\hline 27 & Lantana camera Linn. & Kurri & Verbiniaceae & Common (M) \\
\hline 28 & Pyracantha crenulata (D.Don) & Ghigharu & Rosaceae & Common \\
\hline 29 & Urtica dioica Linn. & Kandali/bichughass & Urticaceae & Common (M) \\
\hline 30 & Vateriana hardwickii Wall. & Samoya/tager & Valerianaceae & Occasonal (M) \\
\hline 31 & $\begin{array}{l}\text { Dioscorea belophylla (Prain) Haines } \\
\text { syn. Dioscorea glabra Hook.f.p.p. }\end{array}$ & Taidu/tarud & Dioscoreaceae & Common (M) \\
\hline 32 & Dioscorea bulbifera Linn. & Gethi/ratalu & Dioscoreaceae & Common (M) \\
\hline 33 & Trichosanthes palmate Roxb. & Ilaadu/indarians & Cucurbitaceae & Common \\
\hline
\end{tabular}


The riparian vegetation in the Kunja stream was observed as rich and conducive for the biological productivity as in another study we have observed rich epilithic periphyton and detritus standing stock along with maco zoobenthos. According to Hynes (1975) there is a strong linkage between riparian vegetation and stream biota. Shyam (2008) linked the importance of riparian vegetation to anthropogenic requirement during his study in river Ganga. Srivastava (2007) has opined that riparians definitely affects the geomorphology and physic chemistry of the river system. Sagir and Dobriyal $(2017,2018)$ have studied the riparian vegetation of Western Nayar and concluded that they form detritus and hence positively affect the production of macrozoobenthos and fishes.

\section{Acknowledgement}

The authors are grateful to Prof. A K Dobriyal, Head of Zoology Department, H N B Garhwal University Campus, Pauri Garhwal for encouragement and critically going through the manuscript. Help in taxonomical identification of plants rendered by Prof N S Bisht, Department of Botany H N B Garhwal University Campus, Pauri Garhwal is also thankfully acknowledged.

\section{References}

Aziem, S., Dasgupta, S., Mishra, A.K., Saha, S. and Yadav, P.K. (2016). Riparian phytodiversity status of pristine Bhilangana valley of Garhwal Himalaya: An undocumented retrospective hitherto. $J$ Biodiverse Manage Forestry 5 (2): http ://dx.doi.org/10.4172/2347-4417.1000156.

Balodi, V.P., Dobriyal, A.K., Joshi, H.K., Uniyal, S.P. \& Thapliyal, A. (2004). Epilithic periphyton and detritus ecology of the springfed stream Eastern Nayar in Garhwal Himalaya. Environmental Conservation Journal. 5(1-3): 1-5

Hynes, H.B.N. 1975 The stream and its valley . Verh. Int. Ver.Limnol. 19, 1 - 15 .

Pusey, B.J and Arthington, A.H. (2003), Importance of the riparian zone to the conversation and management of freshwater fishes :A review, Marine and freshwater Research, No. 54,pp.1-6

Rios,S.L and Baily,R.C (2006).Relationship between riparian vegetation and stream benthic communities at three spatial scales . Hydrobiologia , 553:153-160.

Sagir, M. and Dobriyal, A. K. (2017). Diversity of riparian vegetation in Western Nayar valley on selected experimental spots. J. Mountain Res.12: 115-118.

Sagir, M. and Dobriyal, A.K., (2018). Influence of riparian vegetation on detritus standing stock of western Nayar valley Uttarakhand. Int. Res. Anal. Rev. 5(04): 1051-1064.

Shyam R. (2008). A study on riparian floral biodiversity of river Ganga between Haridwar and Gangotri. Ph. D. Thesis Gurukul Kangri Unversity, Haridwar.

Srivastava, V.K (2007) River Ecology in India : present status and future research research stratergy for management and conservation . Proc.Indian natn Sci Acad. 73 No. 4 pp. 255269. 